\title{
Ethnoecological study on the utilization of plants in Ciletuh- Palabuhanratu Geopark, Sukabumi, West Java, Indonesia
}

\author{
INDRI WULANDARI I,2,3 , BUDIAWATI SUPANGKAT ISKANDAR ${ }^{1,3,4}$, PARIKESIT $^{1,2,3}$, TEGUH HUDOSO $^{1,2,3}$, \\ JOHAN ISKANDAR ${ }^{1,2,3, \vee}$, SYA SYA SHANIDA ${ }^{3}$, ERRI NOVIAR MEGANTARA ${ }^{1,2,3}$, \\ ELMA FAUZIAH GUNAWAN ${ }^{3}$ \\ ${ }^{1}$ Doctoral Program in Environmental Science, School of Graduates, Universitas Padjadjaran. Jl. Dipati Ukur No. 35, Bandung 40132, West Java, Indonesia \\ ${ }^{2}$ Department of Biology, Faculty of Mathematics and Natural Sciences, Universitas Padjadjaran. Jl. Raya Bandung-Sumedang Km 21, Jatinangor, \\ Sumedang 45363, West Java, Indonesia. Tel. +62-22-7796412 line 104, Fax. +62-22-7794545, `email: johan.iskandar@unpad.ac.id \\ ${ }^{3}$ Center of Environment and Sustainable Science, Directorate of Research, Community Services and Innovation, Universitas Padjadjaran. Jl. Sekeloa, \\ Coblong, Bandung 40132, West Java, Indonesia \\ ${ }^{4}$ Department of Anthropology, Social and Politics Science Faculty, Universitas Padjadjaran. J1. Raya Bandung-Sumedang KM 21, Jatinangor, Sumedang \\ 45363, West Java, Indonesia
}

Manuscript received: 24 December 2020. Revision accepted: 10 January 2021.

\begin{abstract}
Wulandari I, Iskandar BS, Parikesit, Hudoso T, Iskandar J, Shanida SS, Megantara EN, Gunawan EF. 2021. Ethnoecological study on the utilization of plants in Ciletuh-Palabuhanratu Geopark, Sukabumi, West Java, Indonesia. Biodiversitas 22: 659-672. Plants can provide benefits for community as food, medicine, fuel, building materials, furniture, and others. Plant utilization should be conducted sustainably in a region with high importance of geological, biological, and cultural diversity, such as in CiletuhPalabuhanratu Geopark, Sukabumi, West Java, Indonesia. This study aimed to reveal: (i) plant utilization by local community in Ciletuh-Palabuhanratu Geopark based on land cover; and (ii) community dependence on the plants being utilized. Method used in this study was mixed of qualitative and quantitative methods using direct observation, semi-structured and structured interviews data collection techniques. The result of study showed that the community in Ciletuh-Palabuhanratu Geopark still uses plants for food (80 species), medicinal plants ( 73 species), livestock fodder ( 9 species), firewood ( 27 species), building materials, furniture (38 species), and others (23 species). The highest plant utilization came from gardens (131 species), home gardens (99 species), natural forests (77 species), dry-paddy fields, and wet-paddy fields (7 species). Generally, various agroecosystems and also forest in Ciletuh-Palabuhanratu Geopark have an important role in providing plant products to fulfill the daily needs of rural people.
\end{abstract}

Keywords: Ciemas Village community, Pelabuhanratu Geopark, plant utilization

\section{INTRODUCTION}

There is a strong relationship between humans and the environment, making environmental conditions strongly influence human life behavior and vice versa. Human behavior in an environment will be affected by ecosystems' ability to provide resources that can be used to maintain human life. Through continuous thinking, reasoning, and experience, one will take immediate resources available to support his daily activities or the needs of his group (Hutauruk et al. 2018). One of such resources provided by ecosystem is the plant.

Plants provide a wide range of uses, such as food, traditional medicines, fuel, building materials, furniture, etc. For example, bamboo is very closely related to people's lives, especially in rural areas. People make household items and livings from this species. Many Indonesian ethnicities, including Sundanese living rural villages in West Java, cannot be separated from bamboo. Bamboo has been used widely for various purposes, such as building materials, home furnishings, handicrafts, foodstuffs, and medicines (Tamang et al. 2013; Honfo et al. 2015; Partasasmita et al.2017; Setiawati et al. 2017).
In terms of ecological functions, bamboo produces the highest amount of oxygen among other trees. Its ability to absorb carbon is also high enough to overcome $\mathrm{CO}_{2}$ concentration in air as known as one of the greenhouse gases that can cause global warming and climate change (MaCCraken 2019). In addition, bamboo serves as a water purifier that can be used to remediate critical soil (Mishara et al. 2014).

Geopark is an area that has outstanding geology, including archaeological, ecological, and cultural values by involving local communities to play a role in protecting and enhancing natural heritage. Geopark is different from other natural conservation areas. Geopark is a protected area on a national scale containing a number of important geological heritage that have important attractions that can be developed as part of an integrated concept of conservation, education, and local economics. Geopark is a form of utilization to achieve sustainable development. Geopark presents natural beauty, harmony of location, archeology, geology, and culture (Yanuar et al. 2018). Meanwhile, the natural conservation areas based on law no.5, 1990 on Conservation of Living Natural Resources and their Ecosystems, natural conservation areas can be divided into 2 categories, namely "Nature Reserve Areas 
(Kawasan Suaka Alam-KSA)" consisting of 'Cagar Alam' (protection of flora and fauna and natural landscapes) and 'Suaka Margasatwa', wildlife reserves (protection of special and unique animal species); and "Nature Conservation Areas (Kawasan Pelestarian Alam-KPA)" consisting of National Parks, 'Taman Nasional', 'Taman Wisata Alam', Nature Tourism Parks; Taman Hutan Raya' Grand Forest Parks, including 'Cagar Biosfer', Biosphere Reserves (Wiratno et al. 2004).

Currently, in the world it has been recorded as having 161 UNESCO Global Geoparks in 44 countries. There are 4 UNESCO Global Geoparks in Indonesia, including Batur UNESCO Global Geoparks (Bali), Gunung Sewu UNESCO Global Geopark (Yogyakarta), Ranjani-Lombok Global Geopark (West Nusatenggara), and CiletuhPalabuhanratu Unesco Global Geoparks (West Java). The Ciletuh-Pelabuhana Ratu Geopark, Sukabumi Regency, West Java, was officially declared a national geopark on 22 December 2015 (Andriany et al. 2016; Yanuar et al. 2018). It has approximately 128,000 hectares, consisting of 74 villages across eight districts, namely Cisolok, Cikakak, and Palabuanratu. Simpenan, Ciemas, Ciracap, Waluran and Surade. The Ciletuh-Palabuhanratu Geopark is characterized by rare geological diversity classified into three zones: uplifted rock subduction zones, the Jampang Plateaus landscape, and ancient magmatic zone shift and forearm evolution (UNESCO 2017). In addition, it has rich biodiversity and local cultural diversity. To preserve nature in Ciletuh-Pelabuhanratu, the geopark concept is used as a sustainable conservation effort (UNESCO 2017).

Some researches on various aspects of the CiletuhPalabuhanratu Geoparks were undertaken, including study on exploration of rock diversity and other geological elements (Andriany et al. 2016; Hadian et al. 2016; Ikhram et al. 2017a; Ikhram et al. 2017b; Wahidah et al. 2017; Pradana et al. 2017; Hardini, et al. 2018); and study on terrestrial and aquatic biodiversity (Sulaksana et al. 2015; Partasasmita et al. 2016; Permatasari et al. 2016; Triana et al. 2017; Wulandari et al. 2018; Winantris et al. 2018; Wulandari et al. 2019; Suhanda et al. 2019; Yuniarti et al. 2019; Riyantini et al. 2020). In addition, study on culture (Supendi 2017; Sobandi et al. 2019) and tourism aspects (Darsiharjo et al. 2016; Yuliawati et al. 2016; Yanuar 2018; Rahardjo et al. 2018; Mustikaningsih et al. 2019) were carried out in the Ciletuh-Palabuhanratu Geopark.

Excellent and appropriate management is needed to support sustainable development in the CiletuhPalabuhanratu Geopark (Wulandari et al. 2018). One important information that can serve as reference for policy and management of the geopark is information on traditional ecological knowledge (TEK) of the local communities. The traditional ecological knowledge is culturally inherited from generation to generation, including traditional knowledge, innovations, beliefs, and practices of indigenous peoples and local communities embodying traditional lifestyles relevant to conservation and sustainable use of biological diversity (Toledo 2002; Berkes 2012; Halim et al. 2012; Iskandar 2018).

Based on an exploratory study undertaken by Padjadjaran University in 2017 (unpublished), 194 plant species (cultivated and non-cultivated) were found in the Ciletuh-Palabuhanratu Geopark. Yet, the information about plant species presented in such study was not completed with local knowledge about plant utilization. Documenting ethnoecological information in the Ciletuh-Palabuhanratu Geopark is immediately important since traditional ecological knowledge owned by the community is only transmitted in oral form from generation to generation (Wulandari et al. 2019). Therefore, written documentation on plant utilization by local community is necessary to avoid knowledge loss. This study aimed to elucidate: (i) plant utilization by local community in CiletuhPalabuhanratu Geopark based on land cover; and (ii) community dependence on the plants being utilized.

\section{MATERIALS AND METHODS}

\section{Study period and area}

This study was carried from February to May 2020 in Ciemas Sub-district, Sukabumi District, West Java Province, Indonesia (Figure 1). Administratively, Ciemas Subdistrict is bordered by Simpenan Subdistrict to the north, the Indian Ocean to the south and to the west, and Ciracap Subdistrict to the east. Ciemas Subdistrict is situated at an altitude of 10-400 meters above sea level (m asl.). Ciemas Subdistrict consists of nine villages, namely Tamanjaya, Mekarjaya, Ciemas, Girimukti, Mekarsakti, Cibenda, Mandrajaya, Ciwaru, and Sidamulya. In this study, however, Sidamulya is not included since this is a new village as the result of expansion program (program pemekaran desa). Besides, Sidamulya is also culturally different from the other eight villages as the residents are majority of Javanese immigrants.

\section{Data collection}

Data collection method used in this study was mixedmethod of qualitative and quantitative using ethnoecological approach as prescribed by Albuquerque et al. (2014) and Iskandar (2018). Based on this approach, the researchers study the point of view of local people who have traditional ecological knowledge on plants embedded with their culture (Berkes 2012). Some techniques in collecting the primary data, including observation, semistructured and structured interviews were employed in this study (Creswell 2009).

The observation was undertaken to obtain general information on local environmental conditions of the villages. The researchers visited and observed village community settlements, forest ecosystems, and various agroecosystem types, including homegardens, gardens, wet-rice paddy fields and dry-paddy fields (swidden cultivation system). 

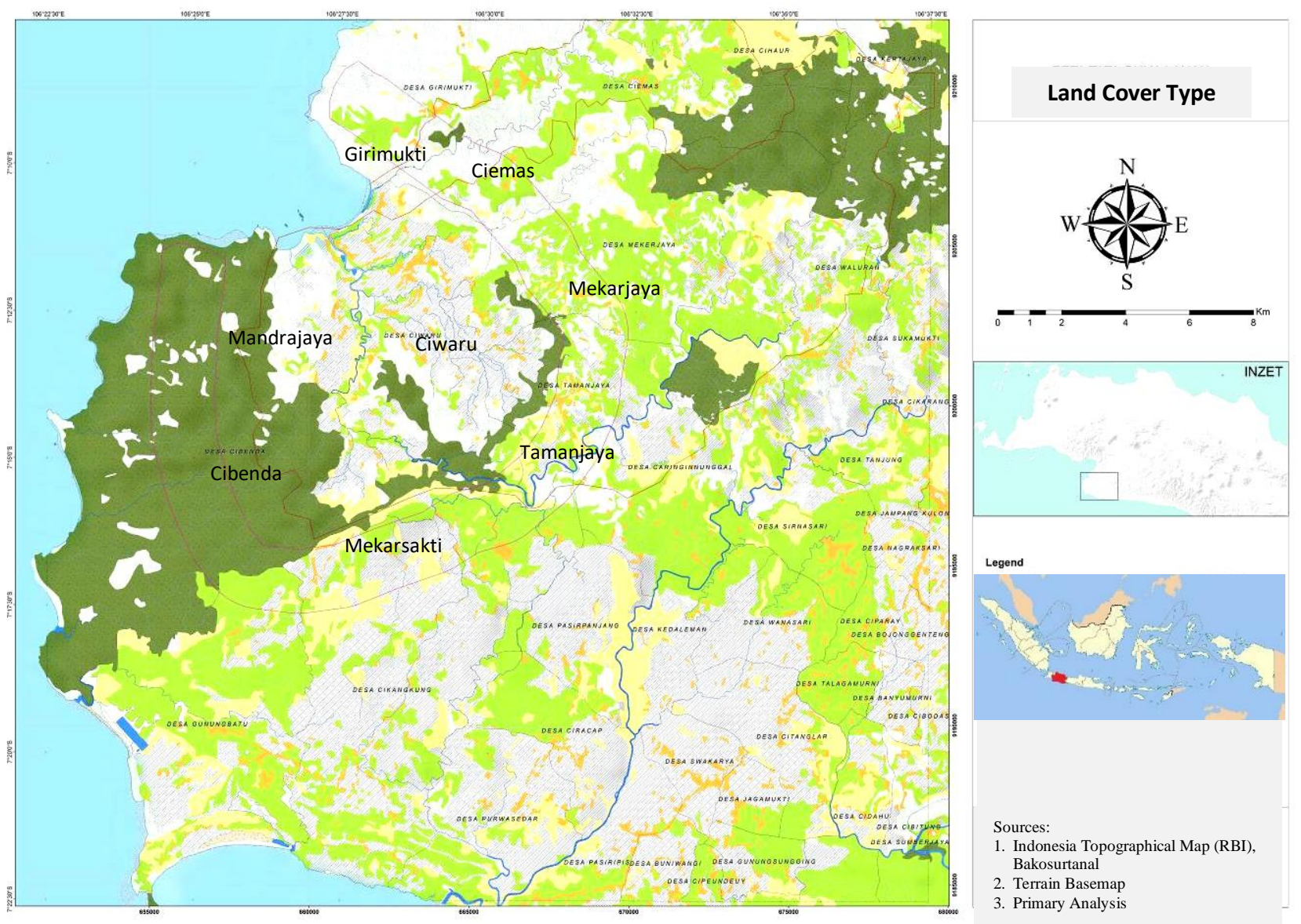

Figure 1. Study area in Ciletuh-Palabuhanratu Geopark, Ciemas Subdistrict, Sukabumi, West Java, Indonesia ( $7^{\circ} 13^{\prime} 7.31^{\prime \prime} \mathrm{S}$ $\left.106^{\circ} 29^{\prime 2} 29.98^{\prime \prime} \mathrm{E}\right)$

The semi-structured interview was conducted to determine plant species used based on the land cover types and community's dependence on plant utilization. The semi-structured interview was conducted through depth interviews with nine key informants of local experts that were purposively selected (Iskandar et al. 2016; Iskandar 2018), with the guidelines for interviews made previously and developed during the interview (Husodo et al. 2019). Informants were chosen through snowball sampling technique by selecting one local expert with excellent knowledge on plant utilization, then based on this initial informant, some other local experts were recognized and purposively selected as informants (Albuquerque et al. 2014). The informants included formal village leaders and their staff, non-formal village leaders, old male and female farmers, village middlemen, agricultural extensions, and tourism managers.

While the structured interview was employed to determine plant species used based on the land cover types only. The interview was conducted using a questionnaire for respondents who were randomly selected. Respondents selected were the household's head, assuming he/she representing his/her family knowledge. The number of respondents was determined based on the Lynch et al. (1974) formula as following:
$\mathrm{n}=\frac{\mathrm{N} \cdot \mathrm{Z}^{2} \cdot \mathrm{P} \cdot(1-\mathrm{P})}{N \cdot \mathrm{d}^{2}+\mathrm{Z}^{2}(1-\mathrm{P})}$

Where;

$\mathrm{n}$ : Number of samples

$\mathrm{N}$ : Population size (15,787 families)

$\mathrm{Z}$ : Number of normal variables $(1,96)$

$\mathrm{P}$ : The greatest possible proportion $(0,50)$

d : Error $(0,10)$

The respondents were selected randomly to be proportional to the population of each village which resulted in a total of 94 respondents (Husodo et al. 2019).

In order to identify unknown plant species, herbarium specimens were made and identified in the laboratory of plant taxonomy, Department of Biology, Faculty of Mathematics and Natural Sciences, University of Padjadjaran, Sumedang, Indonesia.

\section{Data analysis}

The qualitative data was analyzed by cross-checking, summarizing and synthesizing as the basis for developing narrative writing (Newing et al. 2011; Partasasmita et al. 2019). Cross-checking data was conducted using triangulation method using the information obtained from 
informants collected from the interview, observation, and participant observation. While the quantitative data were analyzed using descriptive statistics, including the frequency and proportion of respondents' answers on particular issues (Wulandari et al. 2019).

\section{RESULTS AND DISCUSSION}

\section{Results}

Our study revealed at least 182 species of plants used by village community of Ciemas Subdistrict, consisting of food (80 species), medicinal plants (73 species), livestock fodder ( 9 species), firewoods (27 species), building materials and furniture (38 species), and others (23 species). For more detailed complete species can be seen in Table 1 .

Based on the type of land cover, plants obtained from forest (70 species), gardens (81 species), homegardens (69 species), dry-paddy fields (5 species), and wet-paddy fields (8 species). Based on the data obtained from the interviews, in total the respondents mentioned 116 species, while all the informants mentioned 96 species (Table 2).

\section{Species diversity across land cover types}

As can be seen from Table 1, most plant species used by community in the studied area were documented with various uses including for food, livestock fodder, and fuelwood. However, most plant species for food in the garden is secondary food, while most of the essential foods were cultivated in wet-paddy fields and dry-paddy field. On the other hand, plants used for medicinal purposes were mostly found in the homegardens, while building materials and furniture, and other uses were primarily found in the forests. Despite the low level of species diversity on the paddy field and dry-paddy field, community's dependence on these land-use types was high because their utilization is to fulfill essential food needs in daily life.

\section{Forest}

Based on study results, it revealed that the village people tend to use the forest to obtain firewood. Only a few people use the forest to get food, livestock fodder, and medicinal plants. In addition, logging activities in the Ciletuh-Palabuhanratu Geopark have been banned by the local government and environmentalist communities. Over time, the use of firewood decrease due to concerns that this activity could damage the habitat of Rafflesia patma although many people don't know about the Rafflesia patma and its conservation status, so it needs further education.

Food plants obtained from the forest included billygoatweed (Ageratum conyzoides L.), the barrelier's woodsorrel (Oxalis barrelieri L.), argus pheasant tree (Dracontomelon mangiferum (Blume) Blume), leaved yam (Diocorea hispida Dennst), queensland-cherry (Antidesma bunius L.), cluster fig (Ficus racemosa L.), banana (Musa sp), melastome clearweed (Pilea trinervia Wight), and salak hutan (Eleiodoxa conferta (Griff.) Buret). Only a few people use this food plant. Besides, this food plant is only a side dish, not an essential food.
Table 2. Plant species being utilized by village community in the studied area in Ciletuh-Palabuhanratu Geopark, West Java, Indonesia based on land cover types

\begin{tabular}{lcccccccc}
\hline $\begin{array}{c}\text { Number of species in each } \\
\text { land cover type }\end{array}$ & \multicolumn{6}{c}{$\begin{array}{c}\text { Number of plant species in } \\
\text { each type of use }\end{array}$} \\
\hline $\begin{array}{c}\text { Land cover } \\
\text { types }\end{array}$ & $\begin{array}{c}\text { Number of } \\
\text { species }\end{array}$ & F & M & L & FW & B & O \\
\hline Forest & 47 & 11 & 24 & 4 & 6 & 18 & 14 \\
Garden & 81 & 49 & 31 & 6 & 18 & 17 & 10 \\
Home garden & 69 & 43 & 38 & 1 & 7 & 4 & 6 \\
Dry paddy field & 5 & 3 & 1 & 3 & 0 & 0 & 1 \\
Wet paddy field & 8 & 3 & 1 & 2 & 0 & 0 & 1 \\
\hline
\end{tabular}

Note: F: Food; M: Medicines; L: Livestock Fodder; FW: Fire woods; B: Building Material and Furniture; O: Other

Some people knew the use of plants as medicine from the forest with informants and people who live close to forests, such as Girimukti Village, tended to use this utilization. Some traditional medicine plants, including Ageratum conyzoides L, Blumea balsamifera L, Centella asiatica (L) Urb, Curcuma longa L, and Orthosiphon artistatus (Blume) Miq.

Livestock fodder obtained from the forest included banana (Musa sp), pinto peanut (Arachis pintoi Krapov \& W.C. Greg), and elephant grass (Pennisetum purpureum cv. Mott). These species can still be found in other land covers such as gardens. Usually, breeders herd their livestock by eating wild grass along the roadside, including the natural forests' edge.

Plant species found in the forest used as firewood included hampelas (Ficus ampelas Burm.fil.), njaval (Syzygium densiflorum Wall. ex Wt \&Arn ), teak (Tectona grandis L.f), ki sampang (Melicope latifolia (DC) T.G Hartley), nangsi (Villebrunea rubescens $\mathrm{Bl}$ ), and rengas (Gluta renghas L.). The community knew that various timber plants can be used as firewood when these are dry. Even though there were restrictions in accessing the forest, people tended to take firewood from the gardens, both privately owned and from neighbors, so that the need for firewood for daily life can still be adequately fulfilled.

Timber trees that were used as building materials and furniture can be found in the forest. However, the use of timber trees from the forest was no longer occurring due to the geopark ban. The knowledge on the use of wood from the forest was passed down from previous parents who used the wood.

Other species with various uses, such as spiny bamboo (Bambusa blumeana J.A \& J.H Schultes), whorled bamboo (Gigantochloa verticillata (Willd) Munro ), common bamboo (Bambusa vulgaris Schrad ex J.C.Wendl), giant clumping bamboo (Gigantochloa nigrocillata Kurtz), string bamboo (Gigantchloa apus (Schult F.) Curtz), tamiang bamboo (Schizostachyum blumei Nees), terap (Artocarpus elasticus Reinw. ex Blume), hairy fig (Ficus hispida L.f.), the barrelier's woodsorrel (Oxalis barrelieri L.), mother of cacao (Gliricidia sepium (Jacq) Steud), winged boot tree (Sterculia campanulata Wall. ex Mast), fig tree (Ficus sumatrana Miq), pisang batu (Banana sp.), and pisang 
kepok (Musa acuminata L. x balbisana), can be found in the forest.

Similar study in Talang Mamak Tribe in Riau, Indonesia (Titisari et al. 2019), the utilization of plants varied widely which the plants were obtained from cultivation or extraction from the forest. In this tribe, plants were used for construction materials, foods, medicines and traditional and cultural ceremonies with the utilization of bioresources was carried out by considering the sustainability, function and productivity of forests (Titisari et al. 2019).

\section{Garden and home garden}

Usually, people grew various plant species in their garden and homegarden including woods, bamboos, fruits, spices, medicinal plants, etc. Often the home garden was planted with decorative plants. This result is similar to other studies which found that home garden system in West Java is planted with various diversity of plants which has an important role for ecological and socio-economic functions (Iskandar and Iskandar 2016). Some species of foods, including species and fruits, are commonly grown in both garden and homegarden, such as Allium cepa L, Allium sativum L, Alpinia galanga (L.) Willd, Amomum compactum Soland ex Maton, Capsicum annuum L, Cucumis sativus L, Musa x paradisiaca, Carica papaya L, Lansium domesticum Corr, Muntingia calabura L, and Nephelium lappaceum L.

\section{Dry paddy field and wet paddy field}

Various cultivars of paddy/rice (Oryza sativa L) were cultivated in the studied area. The rice cultivars that grow in the dry field included brown rice (pare pupuay), pare begog, black rice (pare hideung) and glutinous rice (pare sticky rice). In the dry paddy field, the Sundanese people are familiar with the intercropping system (tumpang sari) by growing rice and chayote, banana, cassava, and cucumber. On the other hand, the rice cultivar grown in the wet field was white rice. In this field, the community also grew several species, including maize (Zea mays L), cayenne pepper (Capsicum annuum L.), cowpeas (Vigna unguiculata (L.) Walp) and bananas (Musa sp).

\section{Species diversity across utilization categories Food}

Most people in the studied area still relied on agricultural products to meet their daily needs, both commercial and subsistence. The foods referred to in this study include essential food, fruits, vegetables, and spices. In the land with flat contour, most of the people grew wet rice, while at higher and sloping areas, such as Girimukti, the community tended to grow dry rice.

Based on our observation, people did not have other food alternatives if there is a failure in rice cultivation or other disasters that might cause a reduction in the food supply. For example, if the community experiences a failed rice harvest and runs out of rice stocks, the community borrows rice from neighbors and repay the rice loan when the next crop is made. Besides, people who commercialize rice will experience a decrease in farmers' income. Because of that, people are very dependent on agricultural products.

Of the many plants used as food sources, leaved yam (Dioscorea hispida Dennst) was used as a side dish in the form of chip despite it has risk of poisoning. The use of yam for chip was one of the characteristics of CiletuhPalabuhanratu Geopark in which the community processed the poisonous leaved yam or gadung into chips that are safe for consumption. To get rid of the poison, they have to go through the drying-boiling process for up to 10 days. After that, it can be cooked either steamed or fried into chips, according to taste. Even though it has gone through a long process, hangover symptoms sometimes occur when consumed in large quantities.

\section{Medicinal plants}

The results of the study showed that the community used medicinal plants to cure various diseases. For example, Asiatic pennywort (Centella asiatica (L.) Urb is to treat gout, garden onion (Allium cepa L.) to cure fever, kepel fruit (Stelechocarpus burahol (Blume) Hook and Thomson) to reduce body odor, sea holly (Acanthus ilicifolius L.), god's crown (Phaleria macrocarpa (Sheff) Boerl), white lead tree (Leucaena leucocephala (Lam.) De Wit.), and calabura (Muntingia calabura L) to treat diabetes and high blood pressure. Medicinal plants are a vital source to combat human diseases and play an essential role in healing many serious diseases worldwide due to active phytochemical compounds (Rahmawati et al. 2020). According to Islam and Sarwar (2020), Terminalia arjuna (Roxb.) W \& A) is used to treat heart diseases, Ipomoea alba L. for snakebites, Moringa oleifera Lam. for chickenpox, Vitex negundo for gouts, Centella asiatica (L.) Urb) is used to treat itching in the eye, dry catarrh, and bronchitis. According to Rana et al. (2010), Centella asiatica (L.) Urb) is also used against flatulence, dysentery, and piles bleeding. Other ethnic groups said that Centella asiatica (L.) Urb) is used against diarrhea, menstrual problems, stomach pain, and stimulants (Mohiuddin et al. 2012). Parts of plants commonly used as medicines include leaves, stems, roots, and rhizomes. Leaf, root, bark, herbaceous parts, and seed are the five highest utilization parts of plants (Rahmawati et al. 2020; Karthiyayini 2012; Town 2018).

Besides there were various medicinal plants available in the studied area, some people choose treatment at clinics, health centers, midwives (bidan), mantri (traditional healer), or drugs sold freely in the conventional market. Also, every village has a health center. The rationale of preferring these modern medications is that it is easier to obtain and quicker in the healing process. In addition, not all the parent's knowledge is passed down, so they do not know the dosage of medicinal plants, and they never even try to use medicinal plants. According to Agbor and Naidoo (2016), the main reasons for attending a traditional healer were linked to the educational level, the type of dwelling, and the patient's residence place.

Some people grew medicinal plants in their home garden or asked neighbors' home gardens. The longdistance between the house and the health center/clinic and 
free of cost were the reasons why medicinal plants still being used by the community, especially for first aid, but people turn to modern medicine if they have not recovered. The knowledge on medicinal plants was generally passed down from mothers to daughters, although this knowledge can also be transferred to sons in few cases.

\section{Livestock fodder}

Some people in the studied area owned livestock, such as cows, goats, and sheep. The people used the remaining harvested rice plants and some plants as livestock fodder to feed this livestock. In this study, because only a few people raise livestock, the level of dependence on forage plants was low. Also, as long as there is wild grass on the roadside, livestock can still be used. According to Shiferaw et al. (2018), the primary livestock feed resources were natural grazing lands, crop residues, and cultivated forages such as sesbania (Sesbania sesban), pigeon pea (Cajanus cajan (L) Millsp), and napier grass (Pennisetum purpureum S).

\section{Firewood}

Firewood was obtained from various species of wood plants, mostly from the tree branches and wood/bamboo handicraft waste. Some examples of plants are usually used as firewoods, namely Paraserianthes falcataria L.Nielsen, Bambusa glaucophylla Widjaja, Bambusa vulgaris Schrad ex J.C. Wendl, and Hevea braziliensis (Willdex Juss) Muel.Arg. Also, firewood can be brought from a used lift net. These used lif net only used by fishing communities, such as in Ciwaru and Mandrajaya Villages. People tended to use firewoods for cooking that take a long time, such as boiling water, and people tended to use gas stoves for short cooking times. Firewood was freely available, and people believe that cooking with firewood makes food taste and smell better than using a gas stove. Based on the observation, some of the gas stoves owned were subsidized by the government, so that many people had gas stoves. However, the people were still very dependent on firewood even though they already have a gas stove.

\section{Building material and furniture}

The community in the studied area commonly depends on the use of woods or bamboos for building materials and furniture (Table 1 and Table 2). Some plants are commonly used for building and materials, such as Paraserianthes falcataria L.Nielsen, Albizia procera (Roxb.) Benth, Alstonia scholaris (L) R.Br and Gigantochloa apus (Schult.f) Kurz. The utilization of building materials is predominantly undertaken by men who work as construction workers. Construction workers can build houses (rumah panggung), saung, and furniture such as bamboo benches and tables. According to Setiawati et al. (2017), giant black bamboo is commonly used to make furniture such as tables and chairs. People rarely use timber plants. Also, utilization for buildings is carried out every few years. People tend to buy wood, so people do not depend on this use. Hutaurung et al. (2018) said that the timber is obtained from outside the protected forest area or bought from the village or elsewhere for people who want to build the house.

\section{Other uses}

Several plant species were used traditionally as ropes and fibers, such as string bamboos (Gigantochloa apus Kurz), giant clumping bamboos (Gigantochloa nigrocillata Kurz), hairy figs (Ficus hispida L.f) and sugar palms (Arenga pinnata Merr) (Figure 2). Some bamboos were used as lift nets, such as common bamboo (Bambusa vulgaris Schrad. ex W.C. Wendl.) and spiny bamboo (Bambusa bumeana J.A \& J.H Schultes)) Giant black bamboo (Gigantochloa atroviolacea Widjaja) can be used as a coconut sugar molder, while several bamboos can also be used to make musical instruments, such as bamboo tamiang (Schizostachyum blumei Nees). Several species can be used as additional fertilizers, such as whorled bamboo (Gigantochloa verticillata Willd.) Munro) and mother of cacao (Gliricidia sepium (Jacq) Steud).

The community used terap (Artocarpus elasticus) and banana (Musa sp) for food wrappers, while the barrelier's woodsorrel (Oxalis barrelieri L.) can be used as a hand sanitizer. Several species were used as decorative plants, including hogplum (Spondias mombin L.) and kiara beas/bonsai (Ficus sumatrana Miq). The sap from terap (Artocarpus elasticus Reinw ex. Blume) can be used to catch birds, while beurih (Sterculia campanulata L.) can be used as a bioindicator for forest honey (i.e., if the leaves have fallen off and are left with flowers, it signifies the best quality forest honey season). The honey from the beurih tree is the best honey than the other trees.

Charcoal can use several bamboos, such as spiny bamboo (Bambusa blumeana J.A \& J.H. Schultes ) and common bamboo (Bambusa vulgaris Schrad. ex. W.C. Wendl ). Sassen et al. (2015) said that wood fuel, such as charcoal or firewood, is the most common form of biomass utilized in Sub-Saharan African Countries. Charcoal is a highly consumed form of biomass in Uganda due to the lack of modern alternatives (Dastan et al. 2017; Bamwesigye and Hlavackova 2018; Lee 2013).

Based on this study, it can be concluded that rural people in Ciemas Sub-district, which is the part of CiletuhPalabuhanratu Geopark, still used various plants to meet their daily needs, such as food, medicinal plants, livestock fodder, firewood, building materials, furniture, etc. This variety of uses was provided by high plant diversity on various land covers including forest, garden, home garden, dry paddy field, and wet paddy field. 

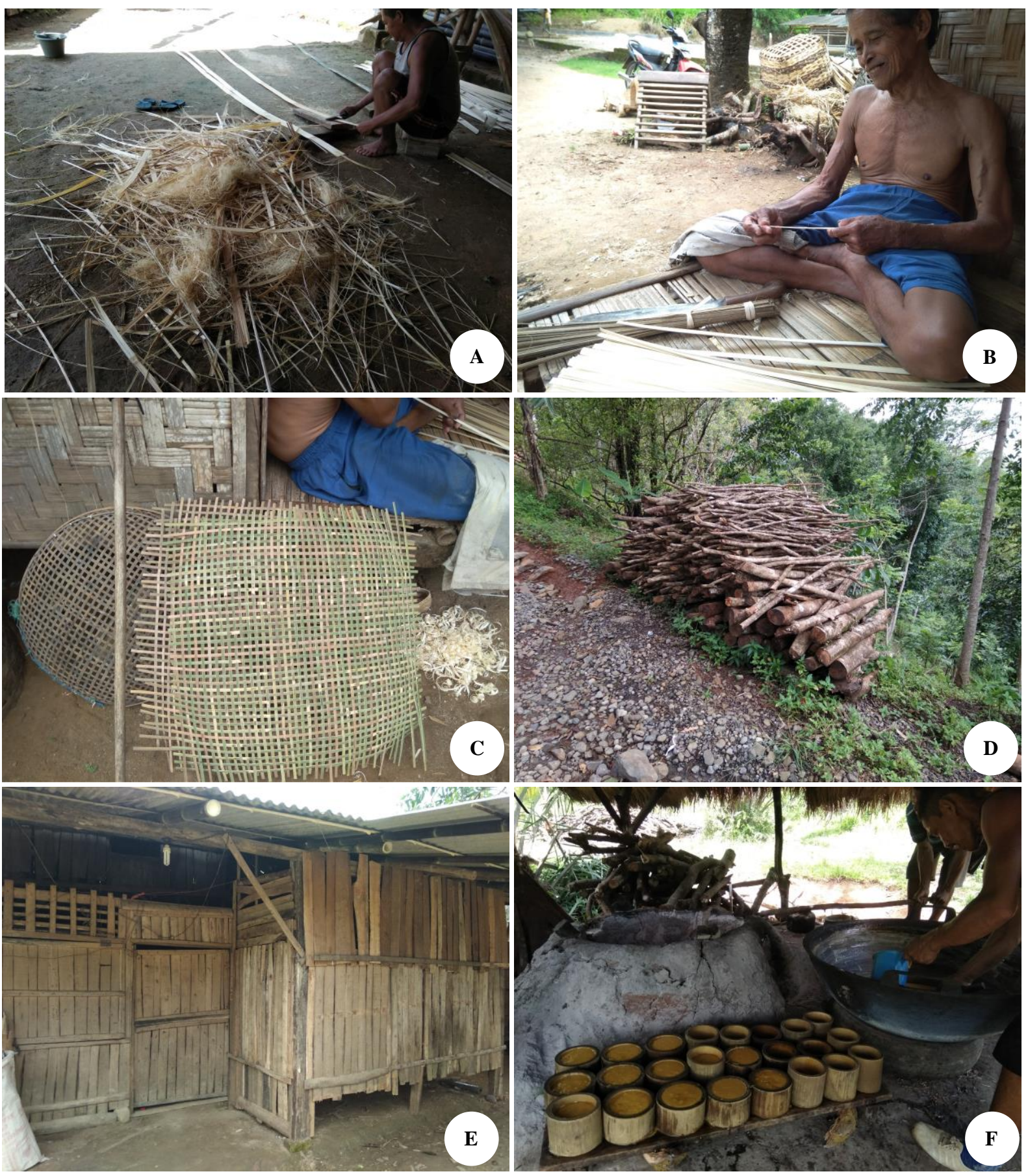

Figure 2. The various utilizations of plants by local communities in Ciletuh-Palabuhanratu Geopark. A-B-C. Bamboo handicraft; D. Collecting of firewood; E. Timber as building material; F. Bamboo as the mold for coconut sugar

\section{ACKNOWLEDGEMENTS}

Special thanks to the Hibah Riset Universitas Padjadjaran Tahun 2020 Skema Riset Percepatan Lektor Kepala (RPLK) Dr. Teguh Husodo. Thanks also to PAPSI staff (Paguyuban Alam Pakidulan Sukabumi), informants and respondents of Ciemas Subdistrict, and surveyor team for supporting the research.

\section{REFERENCES}

Agbor AM, Sudeshni N. 2016. A review of the role of African traditional medicine in the management of oral disease. Afr J Trad Compl Altern Med 2 (13): 133-142. DOI: 10.4314/ajtcam.v13i2.16.

Albuquerque UP, de Lucena RFP, Neto EMFL. 2014. Selection of Research Participants. In: Albuquerque UP, Cruz da Cunha LVF, de Lucena RFP, Alves RRN (eds.). Methods and Techniques in Ethnobiology and Ethnoecology. Humana Press, New York.

Andriany SS, Rosana MF, Hardiyono A. 2016. Ciletuh Geopark Geotourism: Geotrack surrounds the beauty of the Ciletuh Mega 
Amphitheater (The Magical of Ciletuh Amphitheater). Bull Sci Contrib Geol 14 (1): 75-88. [Indonesian]

Bamwesigye D, Hlavackova P. 2018. Forest wood production in Tropical Africa. J Landsc Manag 9 (1): 39-45.

Creswell JW. 2009. Research Design: Qualitative, Quantitative, and Mixed Methods Approach. SAGE Publication, Inc., California.

Darsiharjo D, Supriatna U, Saputra IM. 2016. Ciletuh geopark development based on community participation as a geotourism area in Sukabumi Regency. Jurnal Manajemen Resort dan Leisure 13 (1): 55-60. DOI: 10.17509/jurel.v13il.2036.

Bamwesigye D, Darkwah SA, Hlavackova P, Kupcak V. 2017. Firewood and Charcoal Production in Uganda. Intl Multidiscip Sci Geo Conf SGEM 17: 521-528, DOI: $10.5593 / \mathrm{sgem} 2017 \mathrm{H} / 33 / \mathrm{S} 14.065$.

Berkes F. 2012. Sacred Ecology. $3^{\text {rd }}$ ed. Routledge, New York.

Hadian MSD, Yuliwati AK, Pribadi KN. 2016. Increasing community environmental awareness through geodiversity conservation activities at Ciletuh, Sukabumi, West Java. J Environ Manag Tourism 7 (2): $327-332$

Halim AAB, Othman N, Ismail SR, Jawan JA, Ibrahim NN. 2012. Indigenous knowledge and biodiversity conservation in Sabah, Malaysia. International J Soc Sci Human 2 (2): 159-163. DOI: 10.7763/IJSSH.2012.V2.88.

Hardini ASP, Makalew AND, Munandar A. 2018. Mapping of ecological zones and geomorphological identification of the Ciletuh Geo-area landscape in Sukabumi Regency. Jurnal Lanskap Indonesia. 10 (2): 81-90. DOI: 10.29244/jli.2018.10.2.81-90. [Indonesia]

Honfo H, Tovissodé FC, Gnanglè C, Mensah S, Salako VK, Assogbadjo AE, Agbangla C, Kakaï RG. 2015. Traditional knowledge and use value of bamboo in Southeastern Benin: Implications for sustainable management. Ethnobot Res Appl 14: 139-153. DOI 10.17348/era.14.0.139-153.

Husodo T, Shanida SS, Febrianto P, Pujianto MP, Megantara EN. 2019 Mammalian diversity in West Java, Indonesia. Biodiversitas. 20 (7): 1846-1858. DOI: 10.13057/biodiv/d200709.

Hutauruk TR, Lahjie AM, Simarangkir BDAS, Aipasa MI, Ruslim Y 2018. The prospect of the utilization of non-timber forest products from Setulang Village forest based on local knowledge of the uma longh community in Malinau, North Kalimantan, Indonesia. Biodiversitas 19 (2): 421-430. DOI: 10.13057/biodiv/d190209.

Ikhram R, Rosana MF, Agusta R, Andriany SS. 2017a. Study of significance of geodiversity in Ciletuh-Palabuhanratu National Geopark, West Java, Indonesia. International Conference on Earth Sciences and Engineering (ICEE) 2017, August 29-31, 2017.

Ikhram R, Hardiyono A, Syafitri I, Rosana MF. 2017b. Petrological study of metamorphic rocks in Melange Compex of Ciletuh Area, West Java, Indonesia. International Conference on Earth Sciences and Engineering (ICEE) 2017, August 29-31, 2017.

Iskandar J. 2018. Ethnobiology, Ethnoecology, and Sustainable Development. Plantaxia, Yogyakarta [Indonesian].

Iskandar J, Iskandar BS, Partasasmita R. 2016. Responses to environmental and socio-economic changes in the Karangwang traditional agroforestry system, South Cianjur, West Java. Biodiversitas 17 (1): 332-341. DOI: 10.13057/biodiv/d170145.

Islam MS, Sarwar AKMG. 2020. The garo tribe's ethnobotanical knowledge about medicinal plants. Jordan J Nat Hist 7: 93-107.

Karthiyayini R. 2012. Medicinal plant leaves used by local practitioners of Coimbatore District, Tamil Nadu, India. Intl J Pharma Sci Res 3 (6) 1829-1831

Lee LY. 2013. Household energy mix in Uganda. Energy Econ 39: 252 261. DOI: 10.1016/j.eneco.2013.05.010.

Lynch SJF, Hoelnsteiner RM, Cover CL. 1974. Data gathering by social survey. Philippine Social Science Council, Quezon City.

Mishra G, Giri K, Pandey S, Kumar R, Bisht NS. 2014. Bamboo: potentia resource for eco-restoration of degraded lands. J Biol Earth Sci 4 (2) B130-136.

Mohiuddin M, Alam MK, Basak SR, Hossain MK. 2012. Ethnomedico botanical study among the four indigenous communities of Bandarban, Bangladesh. Bangladesh J Plant Taxon 19: 45-53. DOI: 10.3329/bjpt.v19i1.10941

Mustikaningsih M, Novianti E, Fatma D. 2019. Destination Branding for Ciletuh-Palabuhanratu Ratu Sukabumi tourism area via Geopark. Bull $\begin{array}{lllll}\text { Sci Contrib Geol } 17 & \text { (2): 77-84. DOI: }\end{array}$ 10.24198/bsc\%20geology.v17i2.21779. [Indonesian]

Newing H, Eagle CM, Puri RK, Watson CW. 2011. Conducting Research in Conservation: A Social Science Perspective. Routledge. London.
Partasasmita R, BS Iskandar, S Nuraeni, J Iskandar. 2019. Impact of the green revolution on the gender's role in wet rice farming: A case study in Karangwangi Village, Cianjur District, West Java, Indonesia. Biodiversitas 20 (1): 23-36. DOI: 10.13057/biodiv/d200104.

Partasasmita R, Shanida SS, Iskandar J, Megantara EN, Husodo T, Parikesit, Malone N. 2016. Human-leopard conflict in Girimukti Village, Sukabumi, Indonesia. Biodiversitas 17 (2): 783-790. DOI: $10.13057 /$ biodiv/d170255

Permatasari RE, Noer IS, Jatnika MF, Kusmoro J, Hendrawan R. 2016. Preliminary study of likhen diversity in the Ciletuh Sukabumi Geopark Area, West Java. Prosiding Seminar Nasional MIPA 2016. 89-96. [Indonesian]

Pradana AP, Zakaria Z, Muslim D. 2017. Slope engineering and planning for reinforcement of soil walls in one segment of Ciletuh Road. Padjadjaran Geosci J 1 (2): 141-148. [Indonesian]

Rahmawati N, Mustofa FI, Haryanti S. 2020. Diversity of medicinal plants utilized by To Manui Ethnic of Central Sulawesi, Indonesia. Biodiversitas 21 (1): 375-392. DOI; 10.13057/biodiv/d210145.

Rana MP, Sohel MSI, Akhter S, Islam MJ. 2010. Ethno-medicinal plants use by the Manipuri tribal community in Bangladesh. J For Res 21: 85-92. DOI: 10.1007/s11676-010-00151.

Riyantini I, Ismail MR, Mulyani Y, Gustiani. 2020. Zooplankton as bioindicator of aquatic fertility in the mangrove forest of Ciletuh Bay, Sukabumi Regency. Jurnal Akuatika Indonesia. 5 (2): 86-93. [Indonesian]

Sassen M, D Sheil, Giller KE. 2015. Fuelwood collection and its impacts on a protected tropical mountain forest in Uganda. For Ecol Manag 354: 56-67. DOI:10.1016/j.foreco.2015.06.037.

Setiawati T, Mutaqin AZ, Irawan B, An'amillah A, Iskandar J. 2017. Species diversity and utilization of bamboo to support life's the community of Karangwangi Village, Cidaun Sub-district of Cianjur, $\begin{array}{llll}\text { Indonesia. Biodiversitas } 18 \text { (1): 58-64. DOI: } & \end{array}$ 10.13057/biodiv/d180109.

Shiferaw M, Asmare B, Tegegne F, Molla D. 2018. Farmer's perception and utilization status of improved forages grown in the natural resource areas of northwestern Ethiopia. Biodiversitas 19 (4): 15681578. DOI: $10.13057 /$ biodiv/d190450.

Sobandi B dan Santosa H. 2019. Strengthening the Identity of Geopark Ciletuh through Creating Various Batik Motifs Using Beautiful Natural Environment. Soc Sci Educat Hum Res 255: 16-19. DOI: 10.2991/icade-18.2019.4

Suhanda D, Yuniarti MS, Ihsan YN, Harahap SA. 2019. Nutrient concentration and population of macrozoobenthos in Ciletuh Bay, Sukabumi District, West Java. IOP Conf Ser Earth Environ Sci 406: 012014. DOI: 10.1088/1755-1315/406/1/012014

Sulaksana N, Sjafrudin A, Sukiyah E, Raditya PP, Abdulah F, Setiyanto P. 2015. Land use role in the distribution of erosion vulnerability in the Ciletuh Area of West Java. Bull Sci Contrib Geol 13 (2): 159-167. DOI: 10.24198/bsc\%20geology.v13i2.8402.g3910. [Indonesian]

Supendi DA. 2017. Cultural arts activities in the Sukabumi Geopark Area. Jurnal Surya: Seri Pengabdian kepada Masyarakat. 3 (1). DOI: 10.37150/jsu.v3i1.358. [Indonesian]

Tamang DK, Dhakal D, Gurung S, Sharma NP, Shrestha DG. 2013. Bamboo Diversity, Distribution Pattern and its uses in Sikkim (India) Himalaya. Intl J Sci Res Publ 3 (2): 1-6.

Titisari PW, Elfis, Zen IS, Khairani, Janna N, Suharni N, Sari TP. 2019. Local wisdom of Talang Mamak Tribe, Riau, Indonesia in supporting sustainable bioresource utilization. Biodiversitas 20 (1): 190-197. DOI: $10.13057 /$ biodiv/d200122

Toledo VM. 2002. Ethnoecology: A Conceptual Framework for the Study of Indigenous Knowledge of Nature. In: Stepp JR, Wyndham FS, Zarger RK (eds.). Ethnobiology and Biocultural. The International Society of Ethnobiology, Georgia

Town S. 2018. Assessment of traditional practices of healers to treat human illness in internal medicine. Intern Med 8: 3 DOI: $10.4172 / 2165-8048.1000278$

Triana AE, Hikmat A, Basuni S. 2017. Population of Rafflesia Patma at Leuweung Cipeucang Geopark Ciletuh Sukabumi. Media Konservasi. 22 (2): 196-204. DOI: 10.29244/medkon.22.2.196-204

UNESCO. 2008. Guideline and Criteria for National Geoparks Seeking UNESCO'S Assistance to Join The Global Geoparks Network. UNESCO, Paris.

UNESCO. 2017. UNESCO Global Geoparks, Biosphere Reserves and World Heritage Sites: A Complete Picture. http://www.unesco.org/new/en/ natural-sciences/environment/earthsciences/unesco-global-geoparks/. [January 6, 2021]. 
UNPAD [Padjadjaran University]. 2017. Biodiversity Management in Ciletuh Geopark. Academic Leadership Grant. Technical Report University Padjadjaran, Sumedang. [Indonesian].

Wahidah AN, Arfiansyah K, Ikhram R. 2017. Identification of Clastic Limestone Characteristics as a Building Material in Surade Area, West Java, Indonesia. J Geol Sci Appl Geol 2 (3): 133-141.

Winantris, Rosana MF, Husodo T, Nurjamillah W. 2018. Evaluation of mangrove vegetation before and after reforestation based on pollen data in the Ciletuh-Palabuhanratu Geopark. Jurnal Lingkungan dan Bencana Geologi 9 (2): 97-105. [Indonesian]

Wiratno, Indriyono D, Syarifudin A, Kartikasari A. 2004. Reflecting on Cracked Mirrors: Conservation Reflections and Implications for National Park Management. The Gibbon Foundation Indonesia, PILINGO Movement, Jakarta. [Indonesian].

Wulandari I, Hendrawan R, Husodo T, Megantara EN. 2018. Vegetation structure and composition in Ciletuh Geopark, Sukabumi, Indonesia. Asian J For 2 (2): 54-61. DOI: 0.13057/asianjfor/r020203.
Wulandari I, Shanida SS, Husodo T, Megantara EN, Tresna D. 2019. Animal utilization based on local knowledge in Ciletuh Geopark, Ciemas Subdistrict, Sukabumi, West Java, Indonesia. Biodiversitas 20 (10): 2781-2789. DOI: 10.13057/biodiv/d201001.

Yanuar Y, Anna Z, Hindayani P, Rosana MF, Sudradjat A, Zakaria Z. 2018. Prospective analysis of sustainable development strategy of Geopark Tourism of Ciletuh-Palabuhanratu West Java Indonesia. Int1 J Curr Innov Res 4 (2): 1033-1039. DOI: 10.24327/IJCIR.

Yuliawati AK, Hadian MSD, Rahayu A, Hurriyati R. 2016. Developing geotourism as part of sustainable development at Ciletuh Sukabumi, West Java, Indonesia. J Environ Manag Tourism 1 (13): 57-62. DOI: 10.14505/jemt.v7.1(13).05.

Yuniarti, Ihsan YN, Harahap SA, Suhanda D. 2019. Relationship of sedimentation rate to the structure of macrozoobenthos community on transitional in Ciletuh Bay, Sukabumi District, West Java. IOP Conf Ser Earth Environ Sci 406: 012014. DOI: 10.1088/1755$1315 / 406 / 1 / 012014$ 
Table 1. Plants and various utilizations recorded in the community of Ciletuh Pelabuhanratu Geopark, West Java, Indonesia

\begin{tabular}{|c|c|c|c|c|c|c|c|c|c|}
\hline \multirow{2}{*}{ Family } & \multirow{2}{*}{ Scientific name } & \multirow{2}{*}{ Vernacular name } & \multicolumn{6}{|c|}{ Utilizations } & \multirow[t]{2}{*}{ Main function } \\
\hline & & & Fo & $\mathbf{M}$ & $\mathbf{L}$ & $\mathbf{F i}$ & $\mathbf{B}$ & $\mathbf{O}$ & \\
\hline Acanthaceae & Acanthus ilicifolius $\mathrm{L}$ & Daruju & & $\sqrt{ }$ & & & & $\sqrt{ }$ & \\
\hline Amaranthaceae & Achyranthes aspera $\mathrm{L}$ & Jarong & & $\sqrt{ }$ & & & & $\sqrt{ }$ & \\
\hline Rutaceae & Acronychia pedunculata (L) Miq. & Kayu Semidra & & & & & & $\sqrt{ }$ & Decorative plants (bonsai) \\
\hline Asteraceae & Ageratum conyzoides $\mathrm{L}$ & Babadotan & $\sqrt{ }$ & $\sqrt{ }$ & & & & & Side dishes and stop the nose bleed \\
\hline Fabaceae & Albizia chinensis (Osbeck) Merr & Sengon & & & & & $\sqrt{ }$ & & Building material \\
\hline Fabaceae & Albizia falcataria/ Paraserianthes falacatria $\mathrm{L}$. Nielsen & Albasiah & & & & $\sqrt{ }$ & & & Firewood \\
\hline Fabaceae & Albizia procera (Roxb.) Benth. & Weru & & & & & $\sqrt{ }$ & & Building material \\
\hline Amaryllidaceae & Allium cepa $\mathrm{L}$. & Bawang Beureum & $\sqrt{ }$ & $\sqrt{ }$ & & & & & Kitchen spices and reduce fever \\
\hline Amaryllidaceae & Allium sativum $\mathrm{L}$. & Bawang Putih & $\sqrt{ }$ & & & & & & Kitchen spices \\
\hline Amaryllidaceae & Allium tuberosum Rottler Ex Spreng & Kuсаi & $\sqrt{ }$ & & & & & & Kitchen spices \\
\hline Zingiberaceae & Alpinia galanga (L.) Willd & Lengkuas & $\sqrt{ }$ & $\sqrt{ }$ & & & & & Kitchen spices and lowering blood sugar \\
\hline Apocynaceae & Alstonia scholaris (L.) R.Br. & Lame Putih & & & & & $\sqrt{ }$ & & Building material \\
\hline Apocynaceae & Alstonia sp. & Lame Kuning & & & & & $\sqrt{ }$ & & Building material \\
\hline Amaranthaceae & Amaranthus spinosus $\mathrm{L}$. & Bayam & $\sqrt{ }$ & & & & & & Sidedishes \\
\hline Zingiberaceae & Атотит compactum Soland Ex Maton & Kapulaga Jawa & $\sqrt{ }$ & $\sqrt{ }$ & & & & & Kitchen spices and treat smell breath \\
\hline Zingiberaceae & Amomum dealbatum Roxb & Wresah & & $\sqrt{ }$ & & & & & Reduce fever \\
\hline Anacardiaceae & Anacardium occidentale $\mathrm{L}$. & Jambu Monyet & $\sqrt{ }$ & $\sqrt{ }$ & & & & & Sidedishes and treat diarrhea \\
\hline Bromeliaceae & Ananas comosus (L.) Merr. & Nanas & $\sqrt{ }$ & & & & & & Sidedishes \\
\hline Acanthaceae & Andrographis paniculata Nees & Sambiloto & & $\sqrt{ }$ & & & & & Reduce blood sugar \\
\hline Annonaceae & Annona muricata $\mathrm{L}$ & Sirsak & $\sqrt{ }$ & $\sqrt{ }$ & & $\sqrt{ }$ & & & Firewood, side dishes, reduce back pain and blood pressure \\
\hline Annonaceae & Annona squamosa $\mathrm{L}$. & Srikaya & $\sqrt{ }$ & & & & & & Sidedishes \\
\hline Basellaceae & Anredera cordifolia (Ten.) Steenis & Binahong & & $\sqrt{ }$ & & & & & Relieve fatigue \\
\hline Phyllanthaceae & Antidesma bunius (L) Spreng & Huni & $\sqrt{ }$ & & & & & & Side dishes \\
\hline Apiaceae & Apium graveolens L. & Seledri & $\sqrt{ }$ & $\sqrt{ }$ & & & & & Lowering blood pressure \\
\hline Fabaceae & Arachis pintoi & Kacang Hias & & & $\sqrt{ }$ & & & & Livestock fodder \\
\hline Fabaceae & Archidendron pauciflorum (Benth.) I.C. Nielsen & Jengkol & & $\sqrt{ }$ & & & & & Reduce blood sugar \\
\hline Primulaceae & Ardisia elliptica Thunb & Lempeni & $\sqrt{ }$ & & & & & & Side dishes \\
\hline Arecaceae & Arenga pinnata Merr. & Aren & $\sqrt{ }$ & & & & & $\sqrt{ }$ & Firewood rope, broomsticks making, and as a sweetener \\
\hline Moraceae & Artocarpus altilis (Parkinson) Fosberg. & Sukun & $\sqrt{ }$ & $\sqrt{ }$ & & & & & Side dishes and treat uric acid \\
\hline Moraceae & Artocarpus elasticus Reinw Ex Bl & Benda & & & & & & $\sqrt{ }$ & Catching the bird (sap) \\
\hline Moraceae & Artocarpus heterophyllus Lam. & Nangka & $\sqrt{ }$ & & & & $\sqrt{ }$ & & Side dishes and kitchen furniture \\
\hline Poaceae & Axonopus compressus (Sw.) P.Beauv & Rumput Pahit & & $\sqrt{ }$ & & & & & Adding body insulin \\
\hline Poaceae & Bambusa blumeana Schult \& Schult.f. & Bambu Duri & & & & & & $\sqrt{ }$ & Charcoal and lift net making \\
\hline Poaceae & Bambusa glaucophylla Widjaja & Bambu Putih & & & & $\sqrt{ }$ & & & Firewood \\
\hline Poaceae & Bambusa tuldoides Munro & Bambu Hijau & & & & & $\sqrt{ }$ & & Wicker fence and kitchen furniture \\
\hline Poaceae & Bambusa vulgaris Schrad ex. J.C. Wendl & Bambu Kuning & & & & $\sqrt{ }$ & $\sqrt{ }$ & $\sqrt{ }$ & Building material, firewood, and lift net \\
\hline
\end{tabular}


Fabaceae

Cannaceae

Solanaceae

Caricaceae

Malvaceae

Apiaceae

Cucurbitaceae

Arecaceae

Araceae

Asparagaceae

Asteraceae

Costaceae

Asteraceae

Cucurbitaceae

Cucurbitaceae

Zingiberaceae

Zingiberaceae

Menispermaceae

Poaceae

Urticaceae

Dilleniaceae

Sapindaceae

Poaceae

Dioscoreaceae

Anacardiaceae

Malvaceae

Meliaceae

Poaceae

Arecaceae

Asteraceae

Poaceae

Araceae

Zingiberaceae

Myrtaceae

Moraceae

Moraceae

Moraceae

Moraceae

Clusiaceae

Rubiaceae
Blumea balsamifera (L.)

Boesenbergia rotunda (L.) Mansfeld

Sembung

Bryophyllum pinnatum (Lnk) Oken

Тети Kun

Cajanus cajan (L.) Millsp

Buntiris

Canna discolor Lindl.

Capsicum annuum $\mathrm{L}$

Hiris

Ganyong

Cengek

Carica papaya $\mathrm{L}$.

Ceiba pentandra (L) Gaertn.

Centella asiatica (L.) Urb

Centotheca lappacea (L.) Desv.

Pepaya

Kapuk Randu

Antanan

Rumput Lilit Kain

Citrullus lanatus (Thunb.) Matsumura \& Nakai Semangka

Cocos nucifera $\mathrm{L}$.

Kelapa

Colocasia esculenta (L.) Schott.

Talas

Cordyline fruticosa (L) A Chev.

Hanjuang

Cosmos caudatus Kunth.

Costus speciosus (Koen ex Retz.) Sm

Keniki

Crassocephalum crepidioides (Benth) ex. S.Moore Sintrong

Cucumis sativus $\mathrm{L}$.

Cucurbita moschata Durch.

Curcuma longa Linn.

Curcuma zanthorrhiza Roxb

Bonten

Waluh

Kunyit

Temulawak

Cincau

Sereh

Cymbopogon citratus (DC.) Stapf

Pulus

Dendrocnide stimulans (L fil.) Chew

Sempur

Lengkeng

Dimocarpus longan Lour

Dinochloa scandens (Blume ex Nees) Kuntze

Dioscorea hispida Dennst

Dracontomelon mangiferum (Blume) Blume

Durio zibethinus Murr

Dysoxylum densiflorum Miq

Echinochloa crus-galli (L.) P.Beauv

Eleiodoxa conferta Burett

Elephantopus scaber L.

Eleusine indica (L) Gaertn

Epipremnum aureum (Lind \& Andre) G.S

Etlingera elatior (Jck) R.M. Smith

Eugenia polyantha (Wight) Walp

Ficus ampelas Burm.f

Ficus hispida L.f.

Ficus racemosa Linn

Ficus sumatrana Miq

Garcinia mangostana L.

Gardenia augusta Merr
Bambu Cangkoreh

Gadung

Kadu

Kapinango

Rumput Jajagoan

Salak Hutan

Tapak Liman

Rumput Belulang

Sirih Gading

Honje

Salam

Hampelas

Bisoro

Kiara Beas

Manggis

Kacapiring
Body deodorizer and reduce smell breath

Relieve cough

Reduce fever

Side dishes

Drying out the external wound

Kitchen spices

Treat back pain and lowering the blood pressure

Clean the eyes

Side dishes and treat ulcers

Livestock fodder

Side dishes

Side dishes and firewood

Treat ulcers

Treat dysentery

$\sqrt{ }$ Decorative plants

Eye drops

Side dishes and lowering blood pressure

Sidedishes

Side dishes

Kitchen spices and treat stomach pain

Treat ulcers

Drink

Kitchen spices and clean the eyes

Remove numb body parts

Building material

Firewood

Eye drops

Side dishes

Food

Food

Building material

Livestock fodder

Side dishes

Treat rheumatism

Livestock fodder

Antibiotics

Kitchen spices

Antidote bitter taste in drinks, reduce cholesterol

Making huts and stables

Fire wood ropes

Side dishes

$\sqrt{ } \quad$ Decorative plants (bonsai)

Side dishes

Reduce fever 
Poaceae

Poacea

Poaceae

Poaceae

Phyllan

Anacardiaceae

Malvaceae

Sapindaceae

Euphorbiaceae

Malvaceae

Campanulaceae

Cactaceae

Balsaminaceae

Poaceae

Convolvulaceae

Convolvulaceae

Rubiaceae

Zingiberaceae

Lythraceae

Meliaceae

Verbenaceae

Fabaceae

Cucurbitaceae

Lygodiaceae

Rhamnaceae

Anacardiaceae

Euphorbiaceae

Sapotaceae

Melastomataceae

Rutaceae

Rutaceae

Fabaceae

Rubiaceae

Moringaceae

Moraceae

Muntingiaceae

Musaceae

Musaceae

Musaceae

Musaceae

Rubiaceae

Sapindaceae
Gigantochloa apus (Schult.f) Kurz

Gigantochloa atroviolacea Widjaja

Gigantochloa nigrocillata Kurz

Gigantochloa verticillata (Willd.) Munro

Gliricidia sepium (Jacq.) Steud

Glochidion borneense (Mull.Argr.) Boerl

Gluta renghas $\mathrm{L}$

Grewia acuminata Juss

Guioa diplopetala (Hassk) Radlk

Hevea brasiliensis (Willd ex Juss) Muel.Arg

Hibiscus tiliaceus L.

Hippobroma longiflora (L.) G.Don

Hylocereus undatus

Impatiens balsamina $\mathrm{L}$

Imperata cylindrica Raeusch

Ipomoea aquatica Forssk

Ipomoea batatas $\mathrm{L}$

xora javanica (Blume) DC

Kaempferia galanga Reviw

Lagerstroemia speciosa (L) Pers

Lansium domesticum Cor

Lantana camara Linn

Leucaena leucocephala (Lam) De Wit

Luffa acutangula Roxb

Lygodium sp.

Maesopsis eminii Engl

Mangifera indica L. var.

t esculenta Crantz

Manilkara zapota (L.) P.Royen

Melastoma affine D.Don

Melicope latifolia (DC.) T.G Hartley

Micromelum minutum Wight \& Arn

Mimosa pudica Linn

Morinda citrifolia $\mathrm{L}$

Moringa oleifera Lam

Morus alba $\mathrm{L}$.

Muntingia calabura $\mathrm{L}$.

Musa acuminata

Musa acuminata $\times$ balbisiana

Musa balbisiana

Musa sp.

Neolamarckia cadamba (Roxb.) Bosser

Nephelium lappaceum L.
Bambu Tali

Bambu Hitam

Bambu Lengka

Bambu Gombong

Cebreng

Mareme

Rengas

Derewak

Kihoe

Karet

Waru

Kitolod

Buah Naga

Bunga Pacar Air

Ilalang

Kangkung

Ubi Jalar

Bunga Asoka

Kencur

Bungur

Dukuh

Saliara

Petai Cina

Oyong

Paku Hata

Kayu Afrika

Mangga

Sampeu

Sawo

Harendong

Kisampang

Kihuut

Putri Malu

Mengkudu

Kelor

Murbei

Kersen

Pisang Kole

Pisang Kepok

Pisang Batu

Pisang

Jabon

Rambutan
Building material and bamboo bench straps

Firewood, the material for making roof hut, booths, and lift net

Bamboo bench straps

Building material, lift net, and making liquid fertilizer

Clean the eyes

Side dishes

Firewood and building materia

Firewood

Bamboo bench straps

Firewood

Treat dysentery

Clean the eye

Side dishes

$\sqrt{ }$ Decorative plants

Making roof hut

Side dishes

Treat ulcers

$\checkmark$ Decorative plants

Kitchen spices, treat coughs, and relieve body bruises

Building material

Side dishes

Antibiotics

Treat diabetes

Side dishes

Kitchen furniture making

Firewood and building material

Side dishes and firewood

Side dishes

Side dishes

Treat vaginal discharge

Firewood and building material

Building material

Blood circulation

Antibiotics

Body growth

Reduce cholesterol

Side dishes, reduce blood pressure, uric acid, and cholesterol Side dishes

Sidedishes, treat diarrhea, livestock fodder, and food wrapper Side dishes, treat diarrhea, livestock fodder, and food wrapper Side dishes, treat diarrhea, livestock fodder, and food wrapper Firewood and building material

Side dishes and firewood 


\begin{tabular}{|c|c|c|}
\hline Lamiaceae & Ocimum sanctum Linn. & Kemangi \\
\hline Lowiaceae & Orchidantha longifolia Ridl & Lobak Hutan \\
\hline Lamiaceae & Orthosiphon aristatus (Blume) Miq & Kumis Kucing \\
\hline Poaceae & Oryza sativa L. var. & Padi \\
\hline Oxalidaceae & Oxalis barrelieri L. & Calincing \\
\hline Acanthaceae & Pachystachys lutea Nees & Bunga Lolipop \\
\hline Pandanaceae & Pandanus amaryllifolius Roxb & Pandan Wangi \\
\hline Pandanaceae & Pandanus sp. & Pandan Pecut \\
\hline Pandanaceae & Pandanus tectorius Parkisin ex Zucc & Pandan Gobang \\
\hline Poaceae & Pennisetum purpureumSchumach & Rumput Gajah \\
\hline Lauraceae & Persea americana Mill & Alpukat \\
\hline Thymelaeaceae & Phaleria macrocarpa Scheff & Mahkota Dewa \\
\hline Fabaceae & Phaseolus lunatus L. & Kacang kratok \\
\hline Fabaceae & Phaseolus vulgaris $\mathrm{L}$. & Buncis \\
\hline Phyllanthaceae & Phyllanthus emblica Linn & Malaka \\
\hline Solanaceae & Physalis peruviana $\mathrm{L}$. & Cecenet \\
\hline Urticaceae & Pilea trinervia Wight & Pohpohan \\
\hline Piperaceae & Piper aduncum L. & Sirihan \\
\hline Piperaceae & Piper betle $\mathrm{L}$. & Sirih \\
\hline Piperaceae & Piper caducibracteum C.DC & Sirih Hutan \\
\hline Piperaceae & Piper nigrum L. & Lada Hutan \\
\hline Lamiaceae & Plectranthus scutellarioides (L.) R.Br & Jawer Kotok \\
\hline Asteraceae & Porophyllum ruderale (Jacq) & Ketumbar Bolivia \\
\hline Myrtaceae & Psidium guajava $\mathrm{L}$. & Jambu Biji \\
\hline Fabaceae & Psophocarpus tetragonolobus (L.) DC & Jaat \\
\hline Sterculiaceae & Pterospermum javanicum Jungh & Bayur \\
\hline Euphorbiaceae & Ricinus communis $\mathrm{L}$. & Jarak \\
\hline Poaceae & Saccharum edule Hassk & Trubuk \\
\hline Phyllanthaceae & Sauropus androgynus (L.) Merr & Katuk \\
\hline Theaceae & Schima wallichii (DC) Korth & Puspa \\
\hline Poaceae & Schizostachyum blumei Nees & Bambu Tamiang \\
\hline Cucurbitaceae & Sechium edule (Jacq) Swartz & Lejet \\
\hline Malvaceae & Sida rhombifolia $\mathrm{L}$. & Sidagori \\
\hline Asteraceae & Smallanthus sonchifolius (Poepp \& Endl) H.Robinson & Insulin \\
\hline Solanaceae & Solanum lycopersicum L. & Tomat \\
\hline Solanaceae & Solanum melongena L. & Terong Ungu \\
\hline Solanaceae & Solanum nigrum $\mathrm{L}$. & Leunca \\
\hline Solanaceae & Solanum torvum $\mathrm{L}$ & Takokak \\
\hline Anacardiaceae & Spondias mombin $\mathrm{L}$ & Kedondong Cina \\
\hline Annonaceae & Stelechocarpus burahol (Blume) Hook \& Tomson & Burahol \\
\hline Malvaceae & Sterculia campanulata Wall ex. Mast & Beurih \\
\hline Malvaceae & Sterculia foetida $\mathrm{L}$. & Kepuh \\
\hline Acanthaceae & Strobilanthes crispa $($ L.) Blume & Kijibeling \\
\hline Meliaceae & Swietenia mahagoni $(\mathrm{L}) \mathrm{Jcq}$ & Mahoni \\
\hline
\end{tabular}

Side dishes

Sore throat

Body deodorizer and reduce smell breath

Food and livestock fodder

Side dishes and hand sanitizer

Decorative plants

Relieve stiffness

Mat making

Mat making

Livestock fodder

Firewood

Reduce blood sugar

Side dishes

Side dishes

Sweetener and firewood

Body deodorizer and reduce smell breath

Side dishes

Reduce aches and improves blood circulation

Treat nosebleed

Reduce nausea

Treat bruises

Reduce aches

Treat tinea versicolor

Treat diarrhea

Sidedishes

Building material

Treat rheumatism

Sidedishes

Side dishes and launch a bowel movement

Building material

$\sqrt{ }$ Making flute

Side dishes

Treat uric acid

Treat diabetes

Side dishes

Side dishes

Side dishes

Side dishes

Decorative plants and side dishes

Body deodorizer

$\sqrt{ } \quad \sqrt{ } \quad \sqrt{ }$ Firewood, building material, and forest honey bioindicator Building material

Treat kidney stone

Firewood 


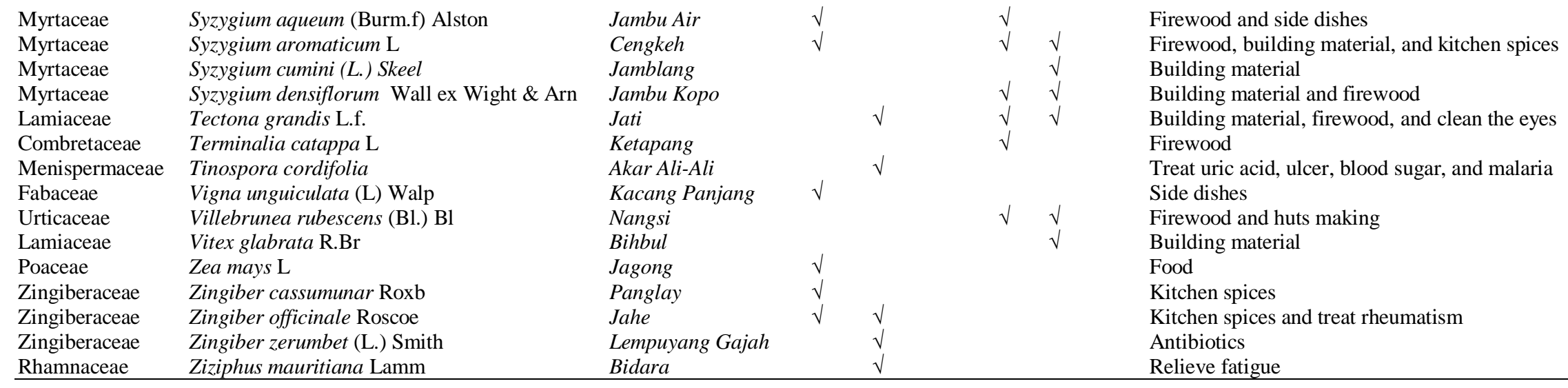

Note: Fo: Food; M: Medicines; L: Livestock Fodder; Fi: Firewoods; B: Building Material and Furniture; O: Others 